Customs Research and Application Journal Vol. 2 No. 12020

\title{
THE COMPARISON OF THE CUSTOMS DUTY AND RICE PRODUCTIVITY IN ASEAN
}

\author{
Patria Yoga A. ${ }^{1}$ and M. Zainul Abidin ${ }^{2}$ \\ ${ }^{1,2}$ Ministry of Finance \\ Notohamiprodjo Building, Jl. Wahidin 1, Jakarta Pusat 10710 \\ Email: patria@kemenkeu.go.id and abidinmz@gmail.com
}

\section{ARTICLE INFORMATION}

Received date

[06-05-2020]

Revision

[20-06-2020]

Accepted date

[28-06-2020]

\begin{abstract}
:
The purpose of this paper is to examine the customs duty to support rice productivity in the ASEAN Member States (AMS). This study uses a qualitative method. The results showed that the customs duty had supported rice productivity in AMS. The rice productivity in AMS has been improved supported by the competitiveness of domestic rice products and supports the welfare of rice producers. Custom duties or imposition of rice tariffs protect the competitiveness of domestic rice, and maintain domestic rice price stability and encourage producer surpluses. Producer surpluses support motivation in rice farming and support consistent increases in rice production. AMS that imposes tariffs on rice, namely: Cambodia, Indonesia, Lao PDR, Malaysia, Myanmar, Philippines, Thailand, and Vietnam. The imposition of customs duties in AMS is based on ad valorem tariffs. AMS that imposes relatively high tariffs on rice is Malaysia and the Philippines. The rice import duty has increased state revenue in AMS that imposes tariffs on rice. In addition, to protect farmers in the form of tariffs, there is a need for greater government support for all people who are active in the rice production system, in the form of improved technology, production inputs, and post-harvest quality improvement. Government supports should also be given in terms of improving distribution channels.
\end{abstract}

Keywords: Customs duty, rice, productivity, trade, ASEAN 


\section{INTRODUCTION}

The ASEAN economy is growing rapidly above the average global economic growth (IMF, 2020). During 2000 - 2008, ASEAN GDP growth reached 5.3 percent. One of the main sectors driving ASEAN economic growth comes from the agricultural sector. In 2018, the agriculture sector will contribute to the economic growth of 10.3 percent.

Table 1. Real GDP Growth ASEAN, 2000 - 2018

\begin{tabular}{lcccccc} 
& \multicolumn{5}{c}{ GDP growth rate (\%) } & \multicolumn{2}{c}{$\begin{array}{c}\text { Annual average } \\
2000-2018\end{array}$} \\
\cline { 2 - 6 } & 2000 & 2005 & 2010 & 2015 & 2018 & 0.8 \\
\hline Brunei Darussalam & 2.9 & 0.4 & 26 & -0.4 & 0.1 & 0.7 \\
\hline Cambodia & 8.4 & 13.6 & 6.0 & 7.0 & 7.5 & 7.7 \\
\hline Indonesia & 5.4 & 5.7 & 6.2 & 4.9 & 5.2 & 5.3 \\
\hline Lao PDR & 5.8 & 7.3 & 8.1 & 7.3 & 6.3 & 7.1 \\
\hline Malaysia & 8.9 & 5.3 & 7.4 & 5.0 & 4.7 & 5.1 \\
\hline Myanmar & 13.7 & 13.6 & 9.6 & 7.0 & 6.8 & 9.8 \\
\hline Philippines & 4.4 & 4.8 & 7.6 & 6.1 & 6.2 & 5.4 \\
\hline Singapore & 8.9 & 7.5 & 15.2 & 22 & 3.1 & 5.2 \\
\hline Thailand & 4.5 & 4.2 & 7.5 & 3.1 & 4.1 & 4.1 \\
\hline Viet Nam & 6.8 & 7.5 & 6.4 & 6.7 & 7.1 & 6.6 \\
\hline ASEAN & 6.0 & 5.8 & 7.5 & 4.8 & 5.2 & 5.3 \\
\hline
\end{tabular}

Source: ASEAN Secretariat, 2019.

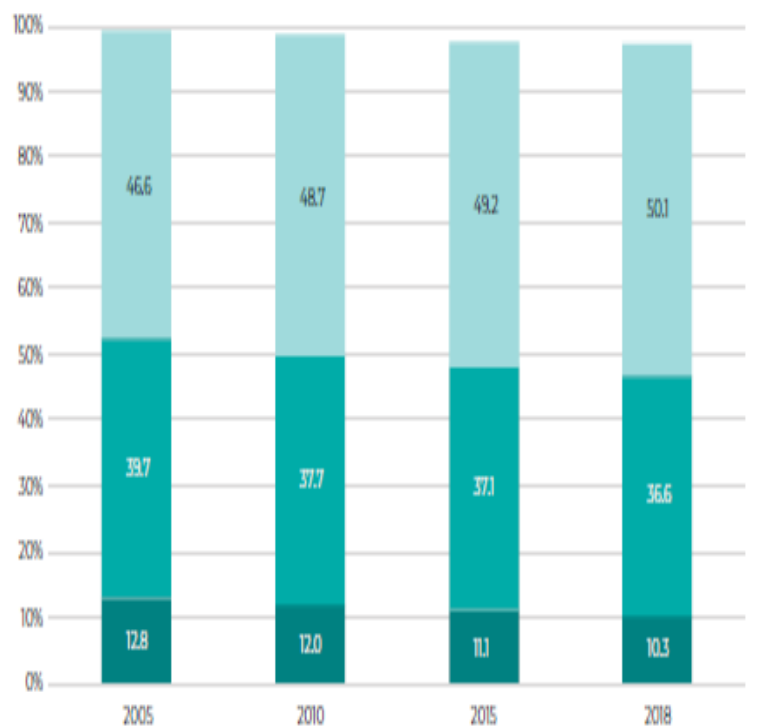

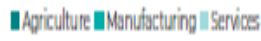


Figure 1. Shares of Economic Sectors to Total ASEAN GDP, 2005-2018

Source: ASEAN Secretariat, 2019.ASEAN is one of the largest population regions in the world with 649.1 million. Between 1980 - 2018, the ASEAN population growth averaged 1.6 percent per year. Most of the ASEAN population aged 20-59 years, reaching 53.7 percent.

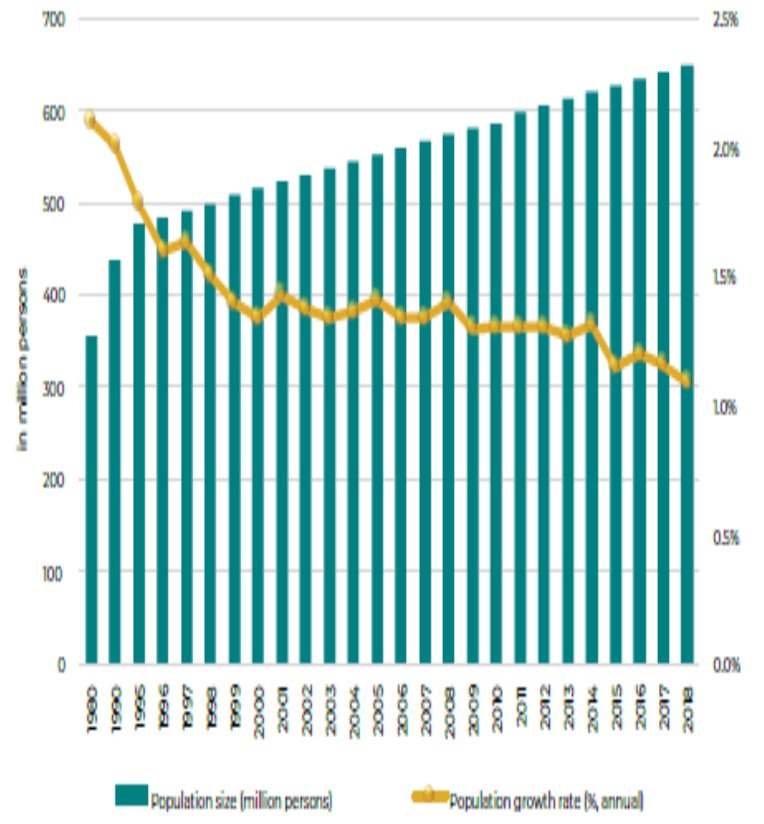

Figure 2. Population and Growth Rates in ASEAN 1980 - 2018 Source: ASEAN Secretariat, 2019.

The agricultural sector is still a source of livelihood for some ASEAN countries. Lao PDR and Cambodia are recorded to have 71.7 percent and 54.9 percent of the population working in the agriculture sector, respectively. Several countries in ASEAN also have a relatively large population working in the agricultural sector. These countries are Myanmar (48.8 percent), Vietnam (41.9 percent), Thailand (35.8 percent), Indonesia (30.5 percent), and the Philippines (28.3 percent). 


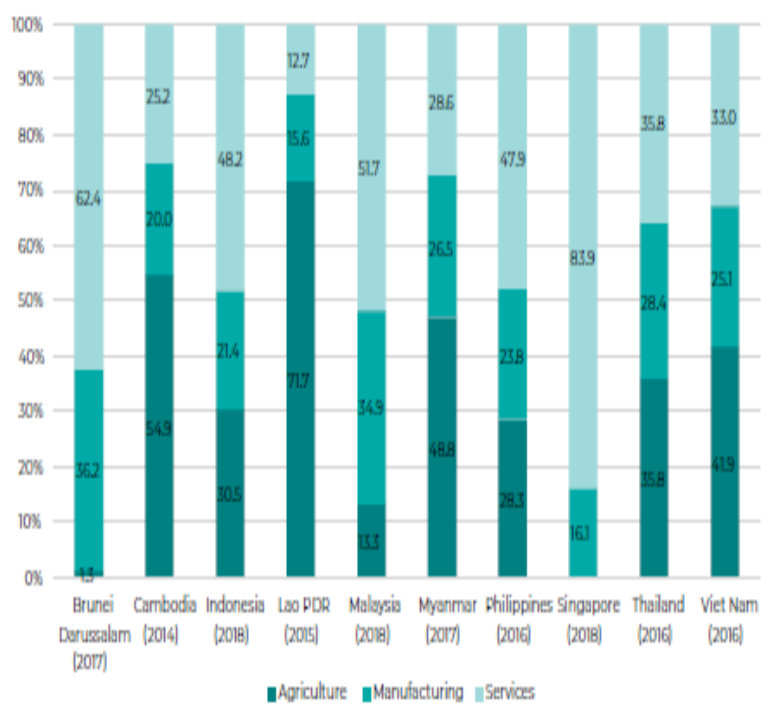

Figure 3. Shares of Employment by Main Economic Sectors (Percent) by ASEAN, Various Years

Source: ASEAN Secretariat, 2019.

The agricultural sector is still a major contributor to the economy in several ASEAN countries. However, the share of agriculture on the economy showed a decline from 12.8 percent in 2005 to 10.6 percent in 2018.

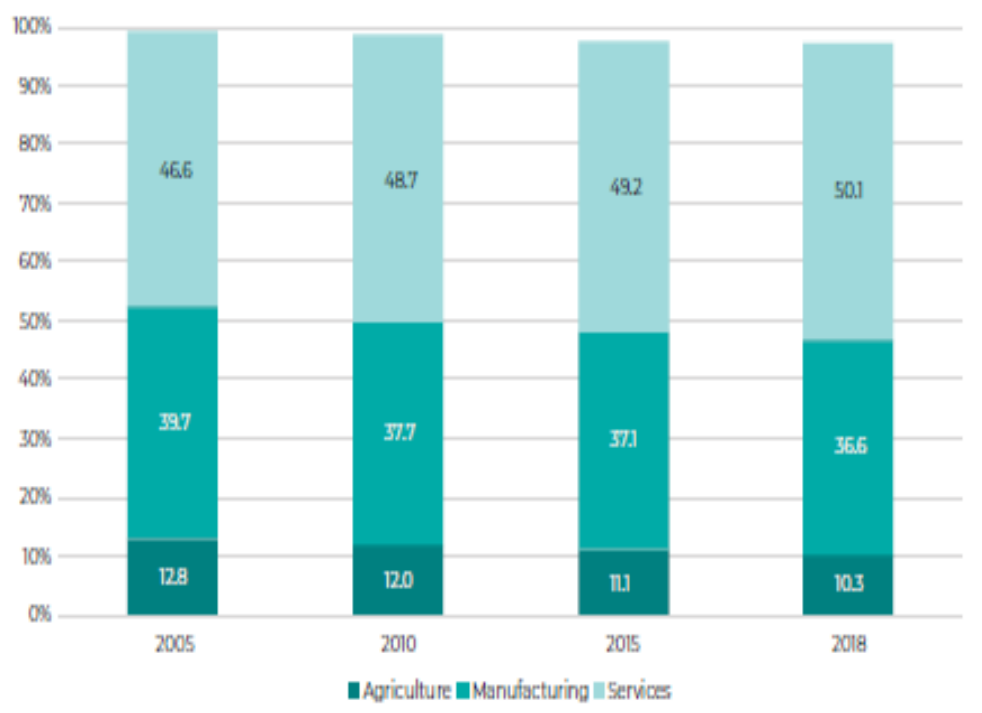

Figure 4. Shares of Main Sectors to Total ASEAN GDP (percent), 2005-2018 Source: ASEAN Secretariat, 2019. 
ASEAN faces major challenges in meeting food needs. As the population increases, the need for food increases. However, the development of the agriculture sector showed a slowdown as reflected in the decline in contributions of the agricultural sector to the economy.

In ASEAN, most of the population consumes staple foods in the form of rice so that rice is an important commodity. In addition, rice is an agricultural commodity that contributes to GDP. The price situation of rice affects the welfare of the community.

Rice is an important commodity of food security and determines welfare in several ASEAN countries. In addition to generating foreign exchange through exports, rice trade also supports regional stability through adequate food for the population. The threat of food security will reduce people's welfare, loss of community productivity, create a country's instability.

Rice trade is one of the important trade commodities in ASEAN. The existence of international trade opens opportunities for domestic consumers to get products / rice at competitive prices (cheaper). However, the flow of imported goods can have a negative impact on domestic producers. In addition, dependence on imported products / rice can threaten a country's food independence.

ASEAN Member States (AMS) has the policy to regulate rice trade. To support domestic rice producers, several ASEAN countries impose customs duty on imported rice. Imposing a customs duty (tariff) on rice imports to increase the price of imported rice on the domestic market. The action maintains the competitiveness of domestic rice against imported rice thereby protecting domestic rice producers.

Several problems resulting from the international trade in rice can reduce productivity, income, and society well-being. Customs duty on certain products is intended to reduce / control the negative impact of international trade on producers and domestic economic actors, thereby supporting the stability of a country's economy. Economic stability supports economic development and the welfare of its citizens.

The ASEAN Member States are heading for efforts to improve the welfare of their people. These efforts can be through fiscal policy instruments. AMS impose customs duty to 
Customs Research and Application Journal Vol. 2 No. 12020

achieve development goals.

The customs duty is considered beneficial for the state budget, and domestic producers. However, there are no studies linking / examine the relevance of customs duty on rice to support rice productivity in the ASEAN Member States.

Studies that focus on rice tariffs in AMS are limited. One of the studies that examined rice tariffs in AMS was conducted by Hoang and Meyers (2015). The study examines the effect of trade liberalization in major rice trading states of ASEAN. The study focuses on the price stabilization mechanism that has long been implemented by Indonesia, Malaysia, and the Philippines. When the country realizes zero rice tariffs, domestic prices decline further in Indonesia and the Philippines, leading to an increase in their imports. However, the impact on domestic prices is absorbed nearly evenly among Indonesia, the Philippines, Thailand, and Vietnam.

Itakura (2014) took that reducing trade barriers has a significantly positive impact on economic welfare. Although there are differences in the magnitude of positive contributions to welfare, all of the FTAs in which the AMSs participate tend to raise welfare. The FTAs leads to the positive effects on real GDP for most of the AMSs.

Mujahid (2016) reviewed ASEAN food reserve and trade using a cost and benefits framework. The study investigates that regional cooperation can significantly reduce the operational cost of holding rice stocks.

The relationship/impact between custom duty and productivity has been reviewed and studied by several studies. Most of this literature only focuses on cases in certain countries. However, there are no studies relating to custom duty factors with rice productivity in ASEAN. Therefore, this study seeks to provide an overview of the customs duty policy in protecting domestic rice farmers to support increased rice productivity in the ASEAN Member States (AMS). This is the essence of this research.

The link between customs duty on rice and rice productivity is the main interest of the author to conduct a study of customs duties to support rice productivity in AMS. The objectives of the study to examine tariffs in protecting domestic rice farmers to support increased rice productivity in AMS. 
Customs Research and Application Journal Vol. 2 No. 12020

\section{LITERATURE REVIEW}

\subsection{Customs Duty}

Customs duties on imported goods are called tariffs. Tariffs provide a price advantage on locally produced goods compared to similar goods imported. In addition, the imposition of tariffs increases revenue for the government (Dastagiri, 2019).

Tariffs are trade restrictions that are considered as indicators of direct restrictions. Some different tariff measures have been used by trade economists: simple average tariffs, average trade-weighted tariffs (most used), and income from import duties as a percentage of total trade.

Customs duty, also called a tariff, are taxes levied on goods shipped across the border (import and export of goods). The words tariff, duty, and customs can be used interchangeably. The tax rate depends on the location and method of making the product. Customs duty types are Basic Customs Duty (BCD), Countervailing Duty (CVD), Additional Customs Duty or Special CVD, Protective Duty, Anti-dumping Duty.

The government uses customs duty to increase revenue, protect domestic industries, and control product movements. Customs duty may be taxed both to increase revenue and to protect the domestic industry. However, taxes intended to increase revenue may have a robust defense effect. The best way to differentiate between income tax and protected tax is a comparison of the impact on domestic and foreign manufacturers.

Tax is protected if products manufactured domestically must be taxed similarly to similar imported goods, or if taxable foreign products are not produced domestically and are not substituted in countries with divergence requirements. Interested for taxes not making pure protection obligations are likely to change production from the export industry to the domestic industry. The coverage, On the other hand, pure obligations do not allow resources to invest in industries that produce taxable products or alternatives to those products. But in the production of goods and services that use more government receipts Divert resources

In terms of income alone, countries change because they can impose comparable taxes on domestic production to protect them or choose to import relatively small amounts of general consumption and set low obligations. There is no inclination for the industry to 
produce taxable (or substituted) goods. On the other hand, if one country wants to protect their industry, the protected product list will be longer and the tax rate will be higher. Political goals often encourage taxation or elimination of customs duties. Customs duties can be divided into three additional groups: shipping tax, export tax, and import tax.

These types of obligations apply to goods originating in one country and being manufactured outside the country from another country. As the name indicates, shipping tax will be charged by the country in which the product was sent through. Such obligations are no longer an main tool in trade policy. However, in the period of merchants (16th-18th centuries) and even in some countries until the middle of the 19th century, they made direct trades and guided that particular route. The development of the German Zolverein (Customs Union) in the first half of the 19th century was part of the use of Prussian authorities to gather transportation services. The most direct and direct impact of transportation customs is the reduction of the amount of goods traded abroad and the increase in the cost of those products to the importing country.

Except taxation of minerals, oil and some agricultural products, export duties are rarely used. Some countries that have many resources rely on export taxes for most of their income. Export customs duties are an important component of a merchant's trade policy. Their main duty is not to increase income. But to protect domestic supply The export tax was first introduced in England by the law which applies to leather and wool in 1275 . In the middle of the 17th century, the list of exportable taxable goods amounted to more than 200 items. Free trade in the 19th century made export rates less attractive. It was abolished in England (1842), France (1857) and Prussia (1865). In the early 20th century, there were only a few countries with export taxation. For example, Spain still uses coke, Bolivia and Malaysia in cans, Italy in Romanian art in forest products. The resurgence of new traders in the 1920s and 1930s caused duplication of exports. In the United States, export taxes are banned by the constitution due to pressure from the South and do not want to restrict the freedom to export agricultural products.

Currently, the export duty is generally charged from the raw material producing countries, not industrial countries. Sometimes, the eroded exchange rates are used to make 
money from the export sector. General taxable exports, such as coffee, rubber, palm oil, and various mineral products, have certain characteristics of export taxes in price policies controlled by the state, which are international partners such as the organization of the oil exporting countries.

Export tariffs are an effective way to protect the domestic industry. For example, Norway and Sweden's obligation to export forest products is primarily determined to promote woodwork and home paper production. Likewise, it was responsible for exporting tan skin from India after World War I in order to encourage India's tanning industry. However, in many cases, customs duties imposed on exports from colonies are intended to safeguard the home country's industry rather than the colonial industry.

If the country that sets the export tax rate is only a small part of the world's exports and the competitive environment is superior, the burden of export customs duties is probably the burden of domestic manufacturers and Given the world price, fewer customs duties and other expenses, but when one country produces the world's major produce and domestic supply is sensitive to the reduced net price, the production will decrease. In such circumstances, the world price tends to increase resulting in an export tax burden for domestic producers and foreign consumers. The extent to which countries can use export tax rates to take advantage of a monopoly on procurement of certain raw materials depends on their success in finding alternatives or new sources.

Customs duties are the most important and used tax category. As mentioned above can be taxed on income and / or protection. But customs duties tend to promote the production of taxable goods in countries that are not economically efficient. It's not enough to raise Although imports are the majority of the existing revenue base But it is advisable to collect all consumption taxes, not just imports to avoid unproductive safeguards.

Import taxes are not an significant source of income in developed countries. For example, in the United States, import tax revenue in 1808 was twice that of all government spending, and in 1837, less than a third of those spending. By the end of the 19th century, US government receipts accounted for half of all revenue. This share was reduced to around 6percent of all revenue before the outbreak of World War II and then decreased further. 
Taxes can be specified individually or complexly, that is a combination of both. Specific obligations are the collection of specific amounts per import unit, such as \$ 1 per yard or pound. On the other hand, advertisements are calculated as a percentage of the value of imports. The true burden of a specific tax rate is inversely proportional to the change in the price of imported goods. But the advertising price provides protection at all price levels (If the price fluctuates at the same rate, both at home and abroad). However, some obligations are more severe to penalize imported goods with lower levels This difficulty can be avoided to some extent by carefully and carefully classifying imported products according to the decoration process. (Raw materials, finished goods, etc.), but the above procedure may result in a very complex and long tax rate Will be created Some customs duties are easier to handle than advertising rates because they often cause administrative problems, especially when valuing imported goods.

A list of all customs duties is typically identified as a tariff schedule. A single tariff schedule use with all imported products regardless of country of origin. This means that there is a single obligation specified in the opposite column of the specified product. Tariffs, two or more rows, offer different rates depending on the country of origin, with reduced rates for goods from countries that have negotiated tariff agreements. Most trade agreements adhere to the MFN Code, including all parties to the agreement, regardless of the concession granted by MFN.

Although all countries have duty-free items and articles that are accepted without obligation, the impact of customs duties on trade by observing at the list and the value of imported goods in that country for free. In addition, it's almost impossible to compare protection levels among countries by measuring the height of the tax wall and calculating the ratio of taxation and total import value. Using this method may conclude that tax protection is extremely limited in countries with more than half of the import being taxexempt. However, these statements are incorrect because some items may have a very high tariff. Higher levels of these tax rates reduce the number of taxable imports.

A better way to measure the height of the tax barrier is to convert all taxes into sales data (depending on the value of the product), then assess the weighted average rate. The 
weight should reflect the relative effects of different imports. For example, a consumer goods tax is more important than a luxury goods tax consumed by a small group.

In addition, effective protection rates can lead to a better understanding of protection. The protection paid to the industry in that country depends on the tax. Inputs collected from the materials used in the production of the product and taxes (products) collected from the final product. For example, suppose that half of the industry's input is imported and 100 percent tax is levied. If the industry has less than 50 percent of its import obligations, there is no effective protection. Effective protection calculations in real-life situations require complex economic analysis.

\subsection{Agricultural Productivity}

Economic output measures the output per unit of input of labor, capital, and other resources. It is usually calculated as the ratio of Gross Domestic Product (GDP) per working hour of the overall economy. The manufacturing sector may be destroyed by the sector to see the trend of labor growth, wage levels and technology improvements, company profits and shareholder returns are directly related to increased productivity.

Productivity is an important source of economic growth and competitiveness. The country's ability to improve living standards depends on the ability to increase production per almost all workers. Economists use productivity growth to simulate economic capacity and consider the use of production capacity. It is used to predict business cycles and predict future GDP growth levels. It also uses capabilities and utilization to assess demand and inflationary pressures.

The most frequently reported production index is labor productivity issued by the Bureau of Labor Statistics. It depends on the ratio of GDP to total time spent on economic activities. The growth of labor productivity is a result of the increased capital available to each employee. (Deep capital increase), education, labor and experience (Elements of labor force), and technological improvements.

However, productivity does not indicate the health of the economy at any time. For example, the 2009 recession in the United States decreased both production and work time 
while productivity increased. Because working hours decrease faster than production As productivity increases can occur during both recession and growth, as in the late 1990s, economic conditions need to be considered when analyzing production data.

Many factors influence the country's production such as investment in factories and equipment, innovation, development of logistics, supply chain, education, companies, and competition. The remaining Solow is generally referred to as the total inputs to measure growth. In the export of an economy that is not caused by the accumulation of capital and labor. It is interpreted as a part of the economic growth caused by management, technology, strategy and financial innovation. This factor, also known as multi-factor production (MFP), compares the number of products and services produced by the number of inputs used in the

production of those products and services. Production factors may include labor, capital, energy, materials, and services purchased.

If the output does not grow significantly, wage increases, company profits and living standards are limited, investments in the economy are at the same level as savings levels, because investments require capital from savings. Low savings rates can reduce labor productivity and investment and true growth. This is why the low savings rates of the United States can undermine future crop growth.

\section{RESEARCH METHODS}

This study uses qualitative methods. According to the objectives of the research, this study is descriptive. Descriptive research is conducted to give more details of the phenomenon. The descriptive research aims to explain the mechanism of the process, present basic information, explain the hierarchy or series and create a set of categories or patterns.

To achieve the research objectives, this research conducted literature research. (Library research) The obtained data are secondary data that can be used as basic data for problem analysis. Data analysis is the process of making data easier in an easier and easier format. Data analysis techniques used are qualitative data analysis techniques. Qualitative data analysis is data management, data organization, organization management, pattern synthesis, search, find, discover important things, learn and define what can communicate with others. 
Customs Research and Application Journal Vol. 2 No. 12020

\section{ANALYSIS AND DISCUSSION}

\subsection{Rice Productivity in ASEAN}

Rice is a unique product for most ASEAN countries. The role of rice is very important because it affects stability and social security. With food prices rising in a short time causing political problems, causing political and economic crises. The stability of rice prices and supply are under national security.

Rice plays an important role in the economy. This is because rice is human food and because rice production is still outstanding in agriculture, the production chain and trade in rice can create Good jobs and value-added. Poor population works in agriculture

The role of rice is constantly being challenged by the threat of a food crisis caused by an imbalance between production (supply) and demand. US international prices can fluctuate broadly and can reach up to 500 percent in a crisis. This creates economic and political instability in countries that rely on rice for food. The relationship between US international commodity transactions makes countries affected by fluctuations in international rice prices.

Increased rice productivity is a major factor in economic growth that helps the poor so that food (rice) is available sufficient at the household level to the country (Hermawan, 2016). Efforts to maintain food production and supply and prices are fundamental. Policy support is needed to improve food production efficiency and more fair and orderly rice trading systems.

ASEAN countries are implementing policies to support increased rice production. However, not every ASEAN country needs sufficient rice in the country. There are many countries in ASEAN that produce rice / rice to meet domestic needs: Cambodia, Myanmar and Thailand. Indonesia is a large importer of rice in ASEAN. ASEAN countries that import rice are the Philippines and Malaysia.

Efforts to increase rice production are still needed to meet the rising domestic demand in many ASEAN countries, especially as the population increases. One effort to increase rice production / rice stems from increased productivity. Increased productivity can be achieved through the use of superior seed technology and the protection of farmers. Therefore, in order to support the improvement of rice and rice production in ASEAN countries, it is necessary 
to support trade policies through tax mechanisms.

Rice is still the staple food of most ASEAN populations, therefore the dependence on this product is very large. Many countries in ASEAN can meet the demand or export from their production. However, many other countries are unable to meet the demand for rice from domestic production and have to import to meet the domestic rice shortage. Production capacities of various countries are affected by policy support to improve access to rice production.

Table 2. Rice Production in AMS (Thousand Tonnes)

\begin{tabular}{|l|c|c|c|}
\hline \multirow{2}{*}{\multicolumn{1}{|c|}{ Country }} & \multicolumn{3}{|c|}{ Year } \\
\cline { 2 - 4 } & 2010 & 2014 & 2018 \\
\hline Brunei Darussalam & 1.07 & 1.38 & 1.56 \\
\hline Cambodia & $8,245.32$ & $9,324.00$ & $10,647.21$ \\
\hline Indonesia & $66,469.39$ & $70,846,46$ & $83,037.00$ \\
\hline Lao PDR & $3,070.64$ & $4,002.42$ & $3,584.70$ \\
\hline Malaysia & $2,464.83$ & $1,834.83$ & $2,718.98$ \\
\hline Myanmar & $32,065.10$ & $26,423.30$ & $25,418.14$ \\
\hline Philippines & $15,772.31$ & $18,967.82$ & $19,066.09$ \\
\hline Thailand & $35,702.94$ & $32,620.16$ & $32,192.08$ \\
\hline Vietnam & $40,005.50$ & $44,974.20$ & $44,046.25$ \\
\hline ASEAN & $203,910.14$ & $209,083.41$ & $220,798.68$ \\
\hline
\end{tabular}

Source: Food and Agriculture Organization, 2020.

The impact of higher rice prices may vary from country to country. Most of these effects increase the number of hungry people. In the Philippines and Indonesia, many countries import rice, which is often poor and not eaten a lot. While in Singapore, many people accept higher food prices without lowering household incomes. Other countries have relatively stable policies.

Rice has unique characteristics: a) 90 percent of rice production and consumption take place in Asia which is different from other region, b) The world rice market is very thin, less than 5 percent of global production, c) Rice prices are more volatile than other food 
products, d) Most of the world's rice trade is monopolized by six countries, namely Thailand, United States of America, Vietnam, Pakistan, China and Myanmar. The efficiency of the response effort is affected by the efficiency of the import market, e) Most Asian countries, rice is considered labor and political goods, so if rice prices are unstable.

Table 3. Rice Targets in ASEAN

\begin{tabular}{|c|c|}
\hline Country & Self-sufficiency Target \\
\hline Brunei Darussalam & Rice self-sufficiency of $60 \%$ over the longer term (2035). \\
\hline Cambodia & No specific self-sufficiency targets. \\
\hline Indonesia & $\begin{array}{l}\text { Whole self-sufficiency ( } 100 \% \text { of domestic production) targets for } \\
\text { rice, maize, soybeans, and beef and sugar. }\end{array}$ \\
\hline Lao PDR & $\begin{array}{l}\text { Production targets for rice and rate of increase targets for other } \\
\text { products. Total quantity targets of food production for some } \\
\text { commodities }\end{array}$ \\
\hline Malaysia & $\begin{array}{l}\text { Self-sufficiency targets for rice of } 90 \% \text { of domestic consumption and } \\
\text { other production targets. }\end{array}$ \\
\hline Myanmar & No specific self-sufficiency targets. \\
\hline Philippines & $\begin{array}{l}\text { Self-sufficiency in rice but later abandoned set year target. Self- } \\
\text { sufficiency in maize production. }\end{array}$ \\
\hline Singapore & $\begin{array}{l}\text { Increase self-sufficiency levels to } 30 \% \text { for eggs, } 15 \% \text { for fish and } \\
10 \% \text { for leafy vegetables. }\end{array}$ \\
\hline Thailand & No specific self-sufficiency targets \\
\hline Vietnam & $\begin{array}{l}\text { Maintain a } 2.5 \% \text { rice yield increase per year until } 2020 \text {, and the set } \\
\text { aside of } 3.8 \text { milllion ha of land specifically for rice production. }\end{array}$ \\
\hline
\end{tabular}

Source: OECD, 2018.

The ability of agricultural land resources owned by ASEAN countries to produce rice and food varies. The average proportion of agricultural land for farmers in food production in ASEAN countries is very diverse, with an average of 0.25 hectares per person. In some countries, the ratio of agricultural land to villagers is higher than the average and in other countries. The ratio is below average. The countries with the highest proportion are Malaysia 
and Thailand, which are 0.52 and 0.47 hectares respectively. Countries with the lowest ratio of farmers to villagers: Myanmar (0.01 hectares) and Indonesia (0.40 hectares).

Based on the area-to-village ratio, it shows that Malaysia and Thailand have the strongest transportation capacity of agricultural areas to provide food sources for rural residents. In contrast, Myanmar has the lowest agricultural area in the ASEAN countries in providing food to village communities. The availability of capacity indicates that the farmland is properly managed to produce products (rice) that can meet the food needs of the population.

Thailand has the highest crop area compared to other ASEAN countries, which is 0.32 hectares per person, Indonesia 0.24 hectares, Cambodia and Malaysia 0.19 hectares. Myanmar has a farm area for a population of 0.01 hectares per person. Vietnam has a production capacity of about 0.11 hectares per person.

Thailand and Indonesia have a strong capacity to transport agricultural land for food to residents. The capability of cultivated land in Thailand and Indonesia to provide food to the villagers and the entire population is equal. This shows that the majority of the population in both countries is in rural areas. Therefore, Thailand and Indonesia are more capable of producing food than other countries.

The ability to supply rice/rice for the rice-growing population in Cambodia was almost 85 times that of Burma's weakest country, 0.17 hectares per person, compared to 0.002 hectares. Myanmar's largest capacity is 78 times that of Indonesia. On the other hand, Indonesia has a production capacity of 0.051 hectares. This picture shows that Cambodia and Thailand have comparative advantages. The best way to provide rice to people in ASEAN. Indonesia lacks comparative advantage in rice procurement because rice farming capabilities for rice populations are only 30 percent of Cambodia's agricultural land.

The ratio of the number of rice farms to the number of farmers can be used as an indicator of whether a farmer can live a good life or not. A higher proportion indicates that rice farming can provide good housing for households. Farming data shows that the rice fields per acre among ASEAN countries are very diverse. On average, at 0.94 hectares per acre. The largest land area in Malaysia is 4.28 hectares per farmer and the Philippines is 2.08 
hectares per farmer. In contrast, Indonesia has an area of less than 0.13 hectares per farmer.

Rice cultivation areas for farms in Indonesia are relatively small. Indonesia is only 0.04 hectares per farmer, better than Myanmar. This situation shows that farmers in Malaysia and the Philippines can live well based on agricultural income. While rice growers in Indonesia and Myanmar cannot meet basic needs if they rely on income from rice cultivation. Although rice cultivation in the country is not very wide. However, the cultivated area per rice field is very small.

Rice production from ASEAN countries up to 1 million tons per year, Indonesia is the third with a production share of approximately 9.9percent, followed by Vietnam, Myanmar and Thailand with a share of 4.9- 6.6 percent. The country that doesn't produce a lot of rice in ASEAN is Malaysia with only 0.3 percent of the production share

In the past two years, the average rice production in ASEAN countries is as high as 3.8 tons per hectare. Vietnam has the highest rice production at 4.9 tons per hectare. Indonesia recorded a yield of 4.6 tons per hectare.

From experience, it is found that the level of rice production is directly proportional to the level of rice cultivation technology used. The use of rice planting techniques includes the use of good quality seeds, fertilizer, the creation of irrigation infrastructure and the selection/determination of nutrient-rich planting areas.

Overall, ASEAN has experienced a surplus in the world market. In the past two years, Every year and the number of rice imported to ASEAN countries that same year. This surplus is expected to increase as ASEAN countries continue to improve rice management continuously and extensively, consuming a variety of foods, especially in those countries where consumption of rice per capita is still high.

There are ASEAN countries that face a surplus in rice trade, namely Thailand, Vietnam and Myanmar. Indonesia deficit of rice trade The largest rice exporter in ASEAN is Thailand. Thailand exported 7.5 million tons of rice. Vietnam is the second largest rice exporter with 4.6 million tons of rice.

There are some ASEAN countries that are rice exporters and importers or purely importers because the country is unable to meet the demand for rice in its country. The main 
importer of rice is Indonesia, which imports 1.8 million tons a year. In addition, the largest import is the Philippines with 1.6 million tons of rice. Malaysia has imported 500,000 tons of rice.

Rice is also a staple food for residents of ASEAN countries. When considering the rice trade information of ASEAN countries, the countries that want to import rice are relatively few, such as Cambodia, Myanmar, and Thailand, which have enough rice production to meet the food demand in the country. Many countries need to import rice, Malaysia. Malaysia's rice imports account for 36percent of the country's rice production. Other countries that want to import to meet domestic rice demand: Philippine and Indonesia. However, the proportion of rice imports to rice production in Indonesia is 3.5 percent and the Philippines is 11.3 percent.

Policies adopted by ASEAN countries to increase rice production, both to meet domestic demand, to increase exports, and to reduce imports. Having a rice development policy in ASEAN countries

The only policy implemented by the Cambodian government to protect farmers is import licenses, which are different from food aid and commercial import. The government imposes a 7percent import tax and 10percent VAT on imports of rice for commercial purposes and is exempt from import duties on rice for food aid.

The Lao PDR government does not use import/export policies specifically. They have problem about significant border control restrictions due to border length and risk of smuggling.

The regime protects the rights of farmers by giving farmers freedom to choose the type of rice to plant in order to stimulate excessive production. The Myanmar government also manages rice prices by purchasing and collecting rice directly from farmers. The government also provides rice polishing and storage services. The Myanmar government has passed the Myanmar Agricultural Trade, which is coordinated by the Ministry of Trade to manage the rice trade policy.

The Philippines is the second-largest rice importer in the world after China in 2017. The Philippines mainly imports rice from Vietnam (52 percent) and Thailand (29 percent) 
(Santiago, 2019).

Thailand is one of the ASEAN countries and still relies on revenue from the foreign exchange from agriculture. The Thai government provides support to exporters in the form of credit for exportation to exporters of agricultural products, especially rice. In addition, the Thai government is also seeking bilateral trade through trade countermeasures mechanism.

Vietnam is ASEAN's second largest rice exporter after Thailand. Success in entering the world market has made policymakers develop new trade policies. Create a balance between efforts to increase national income through rice procurement and rice exports to meet domestic demand at reasonable prices.

Before 1998, the rice policy of Indonesia protected and farmed. At that time, the rice policy instruments were divided into two levels: agricultural level and market/consumer level. Since 1998, the rice policy of Indonesia has changed by canceling all support measures except for the basic pricing in 2001. Indonesia supports the increase of rice production of the country, supports various rice economic activities to increase income. The basic purchase price (government purchase price) and tariff on rice policy has improved rice policy by protect farmers and consumers through regular assessments of import duties and providing rice to the poor.

\subsection{Customs Duty on Rice in ASEAN}

Self-reliance and domestic production are supported by trade policies (OECD, 2018). Rice trade within ASEAN is not included in the regional integration efforts set by AFTA. Therefore, rice trade between member countries ASEAN is therefore under the same tax obstacles as rice trade from non-member countries. In other words, we will not give priority to other ASEAN member countries for rice imports. With two exceptions, both Myanmar and Vietnam use low tariffs for rice trade in ASEAN. However, both are rice exporting countries and imported products may be fed as intermediate inputs in their production activities and then exported again by both countries (OECD, 2018).

In addition to import barriers, many countries have imposed restrictions on rice exports. These are used in response to higher prices in the domestic or international markets and often try to control the prices of domestic consumers. For example, Myanmar has banned 
rice exports in 2004 and 2008 after natural disasters, with previously allowed export restrictions in 2011 and 2013 to access manufacturers and exporters to release products. Inventory and Export Restrictions. Laos has implemented a ban on exports in 2010 in response to severe price increases. The use of flat output in Laos that are available for both the state government and the national government.

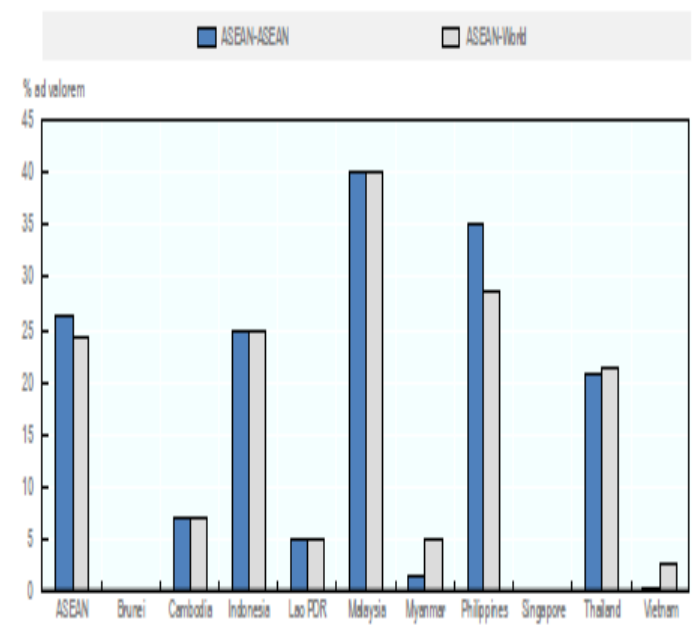

Figure 5. Ad Valorem Tariffs on Rice in ASEAN, 2015-2016 Source: OECD, 2018.

In addition to temporary restrictions and bans, many rice exporters in ASEAN also use accrediting agreements to regulate the level and value of exports. Part of the incentives for such measures is to manage the price and supply in the country in the long run. For example, in Vietnam, rice exports will be handled centrally through a license agreement and state-owned enterprises.

In addition, after the rice price crisis in 2007-2008, the government of Thailand and Vietnam discussed the possibility of adjusting international supply to affect world prices, together with the developed paddy rice pledging scheme. In Thailand (which later failed and demolished) caused the accumulation of large stocks and caused instability in regional and global markets.

\subsection{Custom Duty and Rice Productivity in ASEAN}

Rice is a strategic commodity for many countries, especially in the AMS, because 
most of its population makes rice a staple food. Therefore, food independence in AMS can basically be reflected by its ability to meet its basic food needs, namely rice from its own production.

Until now and the next few years, rice is still a staple food by AMS residents. this makes the AMS population dependent on this commodity is still very large. Regarding rice needs, some AMS countries have been able to meet the needs of rice from domestic production, and there is even more products that can be exported. Conversely, several other AMS countries have only been able to meet these needs from some domestic and imported production.

There are obstacles to suffice the food production and food needs for the population. The high price of rice is due to high demand, rising production costs, lack of agricultural land, and weather and pest problems. In addition, efforts are needed to maintain food supply and rice prices, the need for increased rice productivity, and the need for a fair and orderly trading system.

Increasing rice productivity is very important to meet the food production and food needs of the population and maintain the stability of rice prices. In most countries, the impact of rising rice prices has led to an increase in starving populations. In the Philippines and Indonesia (two rice importing countries with millions of poor people), many people eat less. In Singapore, residents can accept rising rice prices without reducing spending.

There are characteristics of rice commodity trading. These characteristics, namely: the majority of rice production and consumption is carried out in Asia, the world rice market is very thin (4-5 percent of total world production), rice prices are very unstable compared to other food commodities, world rice exporters are only a few countries (such as: Thailand, Vietnam and Myanmar), the stability of most governments in the AMS is strongly influenced by the availability and stability of rice prices.

AMS experienced a rice trade surplus. The amount of rice production is more than the need / consumption of rice in AMS. The surplus will be even greater if AMS continues to improve the management of rice farming intensively and extensively and diversify food consumption, especially in countries where the level of rice consumption per capita is still 
high.

There are ASEAN countries that experience a rice trade surplus, namely: Thailand, Vietnam, Myanmar, and Cambodia. Countries that experience rice trade deficits, namely: Indonesia, the Philippines, and Malaysia.

There are AMS countries that are both exporters and importers as well as purely importers because they have not been able to meet their domestic rice needs. The main rice importing countries in the AMS are Indonesia, followed by the Philippines and Malaysia.

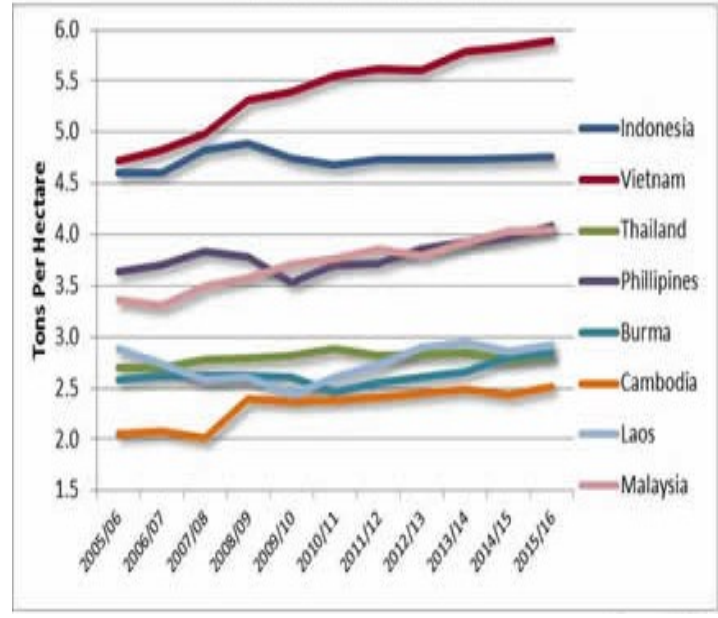

Figure 5. Rice Productivity across ASEAN (Tonnes per hectare, 1961 - 2018)

Source: USDA, 2015

AMS countries have taken various measures to increase rice productivity. As for the policies to increase rice production in several AMS as follows:

\section{Cambodia}

Cambodia's economy is largely based on the agricultural sector. Rice production is essential for this sector because the majority of Cambodian farmers be influenced by directly and indirectly on the realization of the rice harvest each year. Rice production is an key factor in national attempt to support /food security as it is the staple food. Rice is grown mainly during the rainy season (Cramb, Sareth, and Vuthy, 2020).

Cambodia's rice productivity level is 2.40 tons per hectare. To protect farmers, the 
Cambodian government established an import license differentiated between imports for

food aid and for commercial trade. The Cambodian government sets 7 percent import duty and 10 percent VAT on commercial rice imports and exempts rice import taxes for food aid.

Laos

Lao rice production has increased considerably since the early 1990s. It has been driven by the expansion of space and the increase in yield. Rice production in Laos more than doubled over the 1991-2011 period and reached around 3.3 million tonnes of rice in 2011. Laos would continue to generate exportable rice surpluses, even assuming modest production growth and cautious demographic changes. The exportable surplus should reach between 0.45 and 0.5 million tonnes by 2015 . However, the increase in surpluses did not translate into higher incomes for farm households, due to the lower farm gate prices (the price of the product the farm sells) for rice and the increased costs of production (FAO, The World Bank, and IRRI, 2012).

Although increasing surpluses and suppressing producer prices, the government is restricting formal and informal rice and rice exports. The proportion of rice producing households increased from $77 \%$ of all households in $1998 / 99$ to $71 \%$ in $2010 / 11$.

The Lao PDR priorities for rice farming are to promote food security and develop rural livelihoods. Increasing rice productivity support rice self-sufficiency and export the surplus, as well as encouraging crop diversification to reduce risks and increase income (Manivong and Cram, 2020). However, the Laos government has not yet implemented an international trade policy for rice commodities. The rice milling sector is underdeveloped and inefficient, making it difficult to compete for milled rice on regional and international markets.

Indonesia

In Indonesia, the agriculture sector contributes over $13 \%$ of Gross Domestic Product, second largest after manufacturing sector. Rice is important as a staple food and represents the highest calorie intake for more than 250 million people (Mariyono, 2018). 
Indonesia's rice productivity level of 4.62 tons per hectare. The Indonesian government sets import tariffs on rice by Rp450 per kilogram, reducing the difference in the price of imported rice to cheaper domestic rice to maintain the competitiveness of domestic rice in the domestic market. Import tariffs contribute to maintaining the stability of the domestic rice prices and encourage farmers to produce the level of margin / profit in farming is relatively high (Abidin, 2015).

\section{Myanmar}

Agriculture in Myanmar is considered by low productivity, inequality and high instability. Low agriculture productivity turns into labor and land productivity, where both levels of productivity are lower. Agricultural incomes per worker in Myanmar vary from half to a third of the levels in neighboring countries. There are any reasons for this, vary across commodities, but largely stem from chronic long-term underinvestment in agricultural research, weak support, and limited access to credit. Rice yields are lower due to lower levels of input use, especially improved seeds and fertilizers, ineffective weed and pest control, as well as uncertain water management (Ministry of Agriculture and Irrigation, 2015).

Most of rice exports to China cross the borders of Myanmar without a formal import agreement between the two countries resulting in rice is sold at low prices, taxed at high tariffs, and is not recorded in the country's import data (Ministry of Agriculture and Irrigation, 2015).

Myanmar's food security strategy focused on the availability of rice at affordable prices (Myint, 2018). Significant investment in infrastructure will be required to maintain and further increase exports in the long term, targeting a modest level of broken up rice exports of at least 6 million tonnes by 2029-2030. Myanmar is developing short and long term strategies to achieve a vertically integrated value chain that reduces transaction costs and improves efficiency along the chain, from production to marketing. Such efforts were made to compete effectively and successfully in the international rice market (Ministry of Agriculture and Irrigation, 2015).

Myanmar's rice productivity level is 3.83 tons per hectare. The Myanmar government 
controls the price of rice through the purchase and collection of rice directly from farmers. The Myanmar government controls the rice trade policy through Myanmar Agriculture Produce Trading (MAPT) which is under the coordination of the Ministry of Trade.

Thailand

Thailand has long been the $6^{\text {th }}$ largest producer of rice behind China, India, Indonesia, Bangladesh, as well as Vietnam. In the 1950s and 1960s, more than two-thirds of the population lived in rice-producing households, and a major of the rest were involved in the trade, transportation and milling of rice. Despite the growth of other agricultural industries since the 1960s and a decline in per capita rice consumption as incomes increased, rice remains the main agricultural industry, accounting for $51 \%$ of the cultivated area and contributing to the $15 \%$ of agricultural GDP (Suebpongsang, Ekasingh, Cramb, 2020).

Thailand became a significant exporter of rice after the country's opening to world trade in the 1850s. Rice exports increased again in the post-war period. In the 1950s to 1960s, rice represented $43 \%$ of total export earnings, and rice export taxes represented more than $11 \%$ of government revenues. After war period, Thailand was the world's largest exporter of rice, until India surpassed it in 2017 (Suebpongsang, Ekasingh, Cramb, 2020).

The level of productivity of Thai rice is 2.92 tons per hectare. Regarding international trade in rice commodities, the Thai government encourages exports by assisting exporters of rice commodities in the form of export subsidies. In addition, the Thai government is pursuing bilateral trade with a counter trade mechanism.

\section{The Philippines}

The Philippines ranked eighth in global rice production in 2013, but in terms of import volume, the country ranks second after Indonesia. Rice is the staple food for most of the population. The current population is projected to raise to 128 million by 2030 and 142 million by 2040. In 2018, rice is produced on 4.8 million hectares and a total production volume of 19 million tonnes (Tallada, 2019).

The Philippines recently promulgated RA11203 or "The Rice Import, Export and 
Trade Liberalization Act, lifting the quantitative restriction on imports of rice and other purposes for this purpose", the Philippine law on rice tariffs. The law removed quantitative restrictions on imported rice and maintained a 35\% tariff level for rice imported from AMS. With the new rice pricing bill and the influx of cheaper imported rice, the simultaneous reduction of domestic rice prices from $\$ 0.80$ per $\mathrm{kg}$ to $\$ 0.70$ will increase annual consumption of milled rice per capita from $110 \mathrm{~kg}$ to $114 \mathrm{~kg}$, which can translate into total national demand, increased from 13.91 million tonnes in 2019 to 15.88 million tonnes in 2030. In addition, with the implementation of the new law, local farmers were too concerned that the inflow of cheaper rice from abroad, which was feared, could reduce entry prices for local rice fields.

\section{Vietnamese}

In Vietnam, rice production has played a main role in food security, rural employment and foreign exchange. Rice is the most main food crop and accounts for about $50 \%$ of the gross production of other food crops. The area of planted rice harvested increased from 6.8 million hectares in 1995 to 7.5 million hectares in 2015. In 2012, Vietnam has steadily increased its rice production to become the world's second largest rice exporter. The Mekong Delta contains most of the area designated for rice growing, produces $54 \%$ of national rice production and contributes to $95 \%$ of rice exports to Vietnam, which represents 4.7 million tonnes of rice each year. It not only feeds a population of 95 million (OSG, 2018) but also ensures food security in Southeast Asia (Minh, Son, and Trinh, 2019).

Vietnam's productivity level of 4.88 tons per hectare. The Vietnamese government is trying to achieve a rice surplus and increase rice exports. Policies adopted by the Vietnamese government include: establishing food reserves, rehabilitating and developing irrigation networks, developing superior varieties of rice. in addition, the vietnamese government provides agricultural land to the poor without paying rent, guarantees the profitability of rice farmers when prices fall, and provides subsidized loan interest. 
Customs Research and Application Journal Vol. 2 No. 12020

\section{CONCLUSION}

The results showed that the customs duty had supported rice productivity in AMS. The rice productivity in AMS has increased supported by an increase in the price advantage, as experienced by Indonesia. This is supported by the existence of a customs duty that imposes tariffs on rice. The results showed that the customs duty had supported rice productivity in AMS. The rice productivity in AMS has been improved supported by the competitiveness of domestic rice products and and supports the welfare of rice producers. Custom duties or the imposition of rice tariffs protect the competitiveness of domestic rice, and maintain domestic rice price stability and producer profits. Producer profits support motivation in rice farming, and support consistent increases in rice production. AMS that imposes tariffs on rice, namely: Cambodia, Indonesia, Lao PDR, Malaysia, Myanmar, Philippines, Thailand and Vietnam. The imposition of customs duties in ASEAN is based on ad valorem tariffs. AMS that imposes relatively high tariffs on rice are Malaysia and the Philippines. The rice import duty has increased state revenue in AMS that imposes tariffs on rice. It is possible to suggest that revenue from customs duties can be used to help the poor (food subsidies).

The object under study is the tariff policy which is one of the interventions / government support for domestic rice producers (farmers). There are other factors that affect rice productivity improvement. Therefore, the results of this study have not been able to provide a comprehensive picture of increasing rice productivity in AMS.

In addition to protecting farmers in the form of tariffs, there is a need for greater government support for all people who are active in the rice production system, in the form of improved technology, production inputs and post-harvest quality improvement. Government support should also be given in terms of improving distribution channels. Further research is needed on these aspects.

\section{ACKNOWLEDGEMENT}

The author thank the Ministry of Finance of the Republic of Indonesia for facilitating the data collection to complete this research. 
Customs Research and Application Journal Vol. 2 No. 12020

\section{REFERENCES}

Abidin, M. Zainul, (2015). Dampak Kebijakan Impor Beras dan Ketahanan Pangan Dalam Perspektif Kesejahteraan Sosial. Sosio Informa, $1 \quad$ (3). doi:https://doi.org/10.33007/inf.v1i3.168

ASEAN Secretariat. (2019). ASEAN Key Figures 2019. Jakarta: ASEAN Secretariat.

Bello, A.L. (2005). Ensuring food security - A case for ASEAN integration. Asian Journal of Agriculture and Development, Vol. 2/1 and 2, Southeast Asian Regional Center for Graduate Study and Research in Agriculture, Philippines, pp. 87-108.

Chen, B. and S. Saghaian. (2016). Market Integration and Price Transmission in The World Rice Export Markets. Journal of Agricultural and Resource Economics, 41(3), 444457.

Chowdhury, F. L. (2006) Corrupt bureaucracy and privatization of Customs in Bangladesh, Pathok Samabesh, Dhaka.

Cramb R., Sareth C., Vuthy T. (2020). The Commercialisation of Rice Farming in Cambodia. In: Cramb R. (eds) White Gold: The Commercialisation of Rice Farming in the Lower Mekong Basin. Palgrave Macmillan, Singapore

Dawe, D. (2013). Geographic Determinants of Rice Self-Sufficiency in Southeast Asia. ESA Working Paper No. 13-03, Food and Agriculture Organization of the United Nations, Rome.

FAO. (2020). http://www.fao.org/faostat/en/\#data/QC/visualize, accessed 28 April 2020.

Food and Agriculture Organization (FAO), The World Bank, International Rice Research Institute. (2012). Lao PDR: Rice Policy 2012 Report. http://www.fao.org/fileadmin/user_upload/tci/docs/1_Laos\%20document $\% 2010 w \%$ 20resolution.pdf

Freedman, A. (2013). Rice security in Southeast Asia: Beggar Thy Neighbour or Cooperation. The Pacific Review, 26(5), 433-454.

Greenville, J. and K. Kawasaki. (2018). Agro-food Trade, GVCs and Agricultural Development in ASEAN. OECD Food, Agriculture and Fisheries Papers, OECD Publishing, Paris.

Hermawan, Iwan. (2016). Kebijakan Perberasan Indonesia dan Solidaritas Pangan ASEAN. Politica, Vol. 7 No. 1, Mei.

Hoang, H.K. and W.H. Meyers. (2015). Price Stabilization and Impacts of Trade Liberalization in The Southeast Asian Rice Market. Food Policy, Vol. 57, Elsevier, Amsterdam, pp. 26-39.

Itakura, Ken. (2014). Impact of Liberalization and Improved Connectivity and Facilitation in ASEAN. Journal of Asian Economics, Volume 35, December 2014, Pages 2-11. 
Kormych, Borys. (2018). The Modern Trends of The Foreign Trade Policy Implementation: Implications for Customs Regulations. Lex Portus. 5 (5): 27-45. doi:10.26886/2524101X.5.2018.2.

Martin, W. (2017). Agricultural Trade and Food Security. ADB Working Paper Series, no. 664, February 2017, Asian Development Bank Institute, Manilla.

Manivong V., Cramb R. (2020). From Subsistence to Commercial Rice Production in Laos. In: Cramb R. (eds) White Gold: The Commercialisation of Rice Farming in the Lower Mekong Basin. Palgrave Macmillan, Singapore.

Mariyono, J. (2018). Decomposed total factor productivity of Indonesian rice production. Economic Journal of Emerging Markets, 10(2), 121-127. doi: https://doi.org/10.20885/ejem.vol10.iss2.art1.

Minh, Ngo Duc, Doan Hoang Son, Mai Van Trinh. (2019). A Review of Precision Agriculture in Rice Production in Vietnam. FFTC Agricultural Policy Articles. http://ap.fftc.agnet.org/ap_db.php?id=1006\&print=1.

Ministry of Agriculture and Irrigation. (2015). Myanmar Rice Sector Development Strategy. http://books.irri.org/MRSDS_content.pdf

Mujahid, I. and L. Kornher. (2016). ASEAN Food Reserve and Trade: Review and Prospect" in M. Kalkuhl et al. (eds.), Food Price Volatility and Its Implications for Food Security and Policy, Springer, Cham, Switzerland, https://doi.org/10.1007/978-3319-28201-5_17.

Myint, Theingi. (2018). Myanmar's Rice Industry and Policies toward Value Addition and Export, submitted as a paper for the International Seminar on "Promoting Rice Farmers" Market through value-adding Activities, June 6-7, Kasetsart University, Thailand. http://ap.fftc.agnet.org/ap_db.php?id=891

OECD. (2017). Building Food Security and Managing Risk in Southeast Asia. OECD Publishing, Paris, http://dx.doi.org/10.1787/9789264272392-en.

OECD. (2018). ASEAN Rice Market Integration: Findings from a Feasibility Study. $\begin{array}{llll}\text { Working } & \text { Paper } & 7 . & 24\end{array}$ http://www.oecd.org/officialdocuments/publicdisplaydocumentpdf/?cote=TAD/TC/ CA/WP(2018)7/FINAL\&docLanguage=En, accessed 29 April 2020.

Santiago, D. (2019). Philippines Rice Imports by Country. http://www.philippinesaroundtheworld.com/philippines-rice-imports-by-country/, accessed 29 April 2020.

Suebpongsang P., Ekasingh B., Cramb R. (2020). Commercialisation of Rice Farming in Northeast Thailand. In: Cramb R. (eds) White Gold: The Commercialisation of Rice Farming in the Lower Mekong Basin. Palgrave Macmillan, Singapore. 
Tallada, Jasper G. (2019). Precision Agriculture for Rice Production in the Philippines. Food and Fertilizer Technology Center for the Asian and Pacific Region. FFTC Agricultural Policy Articles. http://ap.fftc.agnet.org/ap_db.php?id=1004

USDA. (2015). Southeast Asia: 2015/16 Rice Production Outlook at Record Levels. Commodity Intelligence Report, June 11.

Yap, Normalyn. (2013). Why Does the Philippines Import Rice: A Solution to the Rice Shortage. http://www.nodai.ac.jp/cip/iss/english /9th_iss/fullpaper/1-1-5nchutibao.pdf. pp. 1-3 